\title{
Aromatase activity induction in human adipose fibroblasts by retinoic acids via retinoic acid receptor $\alpha$
}

Jan Wilde, Maria Erdmann, Michael Mertens, Gabriele Eiselt and Martin Schmidt

Institute for Biochemistry II, Jena University Hospital, Friedrich Schiller University Jena, Nonnenplan 4, 07743 Jena, Germany
Correspondence should be addressed to M Schmidt Email martin.schmidt@ med.uni-jena.de

\begin{abstract}
Estrogen synthesis in adipose tissue is associated with the development of breast cancer. Tumors are preferentially found in breast quadrants with strongest expression of the cytochrome P450 aromatase (encoded by the gene CYP19A1). Several promoters regulated by various hormonal factors drive aromatase expression in human breast adipose fibroblasts (BAFs). As adipose tissue is a major source of retinoids, in this study, we investigated their role in the regulation of aromatase expression. The retinoids all-trans-retinoic acid (at-RA) and 9-cis-RA induce aromatase activity in human BAFs. In BAFs, at-RA induces aromatase gene expression via promoter I.4. In 3T3-L1 cells, both retinoids specifically drive luciferase reporter gene expression under the control of aromatase promoter I.4, whereas other promoters active in human adipose tissue are insensitive. Activation by retinoids depends on a 467 bp fragment $(-256 /+211)$ of promoter 1.4 containing four putative retinoic acid response elements (RAREs). Site-directed mutagenesis revealed that only RARE2 $(+91 /+105)$ mediates the retinoid-dependent induction of reporter gene activity. In 3T3-L1 preadipocytes and human BAFs, RA receptor $\alpha$ (RAR $\alpha$ (RARA)) expression is predominant, whereas RAR $\beta$ (RARB) or RAR $\gamma$ (RARG) expression is low. Electrophoretic mobility shift assays with nuclear extracts obtained from human BAFs and 3T3-L1 cells identified a specific RARE2-binding complex. Retinoids enhanced complex formation, whereas pre-incubation with anti-RAR $\alpha$ antibodies prohibited the binding of RAR $\alpha$ to RARE2. Chromatin immunoprecipitation showed RA-dependent binding of RAR $\alpha$ to the RARE2-containing promoter region in vivo. Furthermore, we provide evidence that RARE2 is also necessary for the basal activation of promoter I.4 in these cells. Taken together, these findings indicate a novel retinoid-dependent mechanism of aromatase activity induction in adipose tissue.
\end{abstract}

\footnotetext{
Key Words

- estrogen synthesis

- adipose tissue

- promoter

- all-trans-retinoic acid

- 9-cis-retinoic acid

- retinoic acid receptor $\alpha$

- EMSA

- site-directed mutagenesis
}

Journal of Molecular Endocrinology (2013) 51, 247-260

\section{Introduction}

Estrogen synthesis in adipose tissue is the major source of circulating estrogens in aging men and women. Besides this, the finding of elevated aromatase activity and aromatase mRNA expression in the adipose tissue of breast quadrants harboring breast tumors more directly indicates a link between adipose tissue aromatase and tumors http://jme.endocrinology-journals.org DOI: 10.1530/JME-12-0129
(C) 2013 Society for Endocrinology Printed in Great Britain
Published by Bioscientifica Ltd 
(O'Neill et al. 1988, Bulun et al. 1993). In humans, there exists only one aromatase gene (CYP19A1), which is expressed in the gonads and various extragonadal tissues. Tissue-specific expression depends on the utilization of tissue-specific sets of promoters, which give rise to aromatase transcripts with unique $5^{\prime}$-ends encoded by specific untranslated first exons. As all these first exons are spliced to exon II upstream of the translational start site, the transcribed protein is identical in all tissues (Bulun \& Simpson 1994, Simpson et al. 1994, Simpson 2003, 2004, Chen et al. 2009).

Aromatase expression in adipose tissue is confined to the stromal vascular fraction of cells (Ackerman et al. 1981). There it is under the control of several promoters, which are regulated by specific sets of hormonal factors. In normal adipose tissue, promoter I.4 is dominant (Simpson 2004). It is induced by glucocorticoids (Simpson et al. 1981) in combination with an array of cytokines (Schmidt \& Loffler 1994, Zhao et al. 1995b, 1996b). Induction is inhibited by progesterone (Schmidt et al. 1998) or ligands of the peroxisome proliferator-activated receptor- $\gamma$ (PPARG; Rubin et al. 2000, 2002). In adipose tissue in the vicinity of many breast tumors, promoter II is dominant, whereas it is not normally used in adipose tissue. This promoter is induced by cAMP-elevating agonists, e.g. dibutyryl cAMP, forskolin, and prostaglandin E2, and is inhibited by ligands of the retinoid X receptor (RXR; Simpson et al. 1994, Zhao et al. 1996a, Rubin et al. 2002, Safi et al. 2005).

Retinoids are stored in adipose tissue, mainly as retinyl esters. As hormone-sensitive lipase has strong retinyl ester hydrolase activity, free retinoids are readily available within adipose tissue (Strom et al. 2009). A potential link between adipose tissue concentrations of retinoids and their precursors, carotenoids, and breast cancer risk has been discussed controversially. Two previous studies have found no or an inverse correlation (Zhu et al. 1995, Zhang et al. 1997), whereas a newer study based on more than 400 cases has identified a positive correlation of adipose tissue retinoids with breast cancer risk (Zaroukian et al. 2005).

As the development of most breast cancers depends on the availability of estrogens, we hypothesized that retinoids may be involved in the induction of aromatase expression in breast adipose fibroblasts (BAFs). In this study, we show that ligands of the retinoic acid receptors (RARs), all-trans-RA (at-RA) and 9-cis-RA (9cis-RA), induce aromatase activity in human BAFs via a retinoic acid response element (RARE) in aromatase promoter I.4. RAR $\alpha$ gene $(R A R A)$ is the dominant RAR expressed in the cells used in the present study, human BAFs and 3T3-L1 cells, and is essential for the formation of a specific
DNA-binding complex on the RARE. Furthermore, we show that the RARE necessary for retinoid-mediated induction is also used for the basal induction of the aromatase promoter I. 4 .

These findings suggest that in addition to the well-established glucocorticoid- and cAMP-dependent pathways, an independent, retinoid-dependent mechanism exists for aromatase activity induction in human adipose tissue.

\section{Materials and methods}

All chemicals used were of analytical or cell culture grades. Retinoids were obtained from Sigma-Aldrich.

\section{Cells and cell culture}

Human breast adipose tissue for the preparation of the stromal vascular cell fraction, where adipose fibroblasts make up more than $80 \%$ of the cells (Schmidt et al. 1998), was obtained during plastic surgery from healthy donors. The donors gave informed consent according to a protocol, which was approved by the Ethics Committee of the Jena University Hospital. BAFs were isolated and cultured in medium 199 containing 10\% (v/v) FCS as described previously (Schmidt \& Loffler 1998). BAFs were kept in a humidified atmosphere with $5 \% \mathrm{CO}_{2}$ at a temperature of $37^{\circ} \mathrm{C}$. 3T3-L1 cells were obtained from the ATCC (Manassas, VA, USA) and essentially maintained as described previously (Green \& Meuth 1974). These cells were kept under 7.5\% $\mathrm{CO}_{2}$ in DMEM containing $10 \%(\mathrm{v} / \mathrm{v})$ FCS until used in the experiments. All the experiments involving the stimulation of the cells were carried out under serum-free conditions in a serum-free medium consisting of DMEM and Ham's F12 medium at a ratio of 3:1 (without phenol red and with $7.5 \mathrm{mM}$ HEPES, $\mathrm{pH} 7.2$ ), which was supplemented with gentamicin $(40 \mu \mathrm{g} / \mathrm{ml})$, transferrin $(2 \mu \mathrm{g} / \mathrm{ml})$, pantothenate $(17 \mu \mathrm{M})$, biotin $(1 \mu \mathrm{M})$, and insulin $(1 \mathrm{nM})$. During the experiments, all the cells were kept under $5 \% \mathrm{CO}_{2}$.

\section{Induction of aromatase activity and assay of the aromatase enzymatic activity}

Aromatase activity was tested with the ${ }^{3} \mathrm{H}-\mathrm{H}_{2} \mathrm{O}$ release assay essentially as described previously (Ackerman et al. 1981), with some modifications: confluent monolayers of BAFs in 24-well plates were washed free from growth medium containing FCS with a serum-free medium and incubated for $48 \mathrm{~h}$ with replacement of the medium

Published by Bioscientifica Ltd. 
after $24 \mathrm{~h}$. Then, aromatase activity was induced in a serum-free medium for $24 \mathrm{~h}$ with at-RA, 9cis-RA, or a vehicle (ethanol) only. $\left[1 \beta, 2 \beta-{ }^{3} \mathrm{H}\right]$-testosterone $(50 \mathrm{nM}$, $1 \mu \mathrm{Ci} /$ well) was added as a substrate for the aromatase enzyme $6 \mathrm{~h}$ before the termination of incubation. Cellular protein contents were measured as described previously (Schmidt \& Loffler 1998). Aromatase activity is reported as fmol testosterone used/mg protein per $6 \mathrm{~h}$.

\section{Quantification of aromatase mRNA expression}

BAFs were cultured in $10 \mathrm{~cm}$ dishes and treated as described above. RNA was isolated using the RNeasy Mini Kit (Qiagen). DNase digestion of genomic DNA was carried out on spin columns. RNAs were checked for integrity by gel electrophoresis and stored with recombinant RNasin Ribonuclease Inhibitor (Promega). Subsequently, cDNA was synthesized with the High-Capacity cDNA Archive Kit using random hexameric primers (Applied Biosystems). Real-time PCR analysis was carried out on a StepOnePlus instrument (ABI - Life Technologies). Specific assays were developed using the Universal Probe Library system (Roche), and analyses were carried out according to the manufacturer's standard instructions. All assays yielded homogenous products of the correct size. The following assays were used (name, forward primer, reverse primer, probe): full length (exons IX-X), 5'-CAA ACC CAA TGA ATT TAC TCT TGA, 5'-ACC ATG GCG ATG TAC TTT CC, probe 76; promoter I.4, 5'-CAG CCC ATC AAA CCA GGA, 5'-CAT GGC TTC AGG CAC GAT, probe 9; promoter I.3, 5'-CTT GCC TAA ATG TCT GAT CAC ATT A, 5'-CAT GGC TTC AGG CAC GAT, probe 9; promoter II, 5'-CCC TTT GAT TTC CAC AGG AC, 5'-CAT GGC TTC AGG CAC GAT, probe 9; and GAPDH, 5'-AGC CAC ATC GCT CAG ACA C, 5'-GCC CAA TAC GAC CAA ATC C, probe 60. All the samples were analyzed in duplicate. Relative gene expression was normalized to GAPDH mRNA levels using the comparative cycle threshold $(\mathrm{Ct})$ method, and it is reported as an expression ratio using $2^{-\Delta \Delta C t}$ (Pfaffl 2001).

\section{Promoter constructs and mutagenesis}

Fragments of various promoter regions of the human aromatase gene were PCR-amplified from genomic DNA isolated from blood samples using the QIAamp DNA Blood Mini Kit (Qiagen). PCR starting with 50 ng genomic DNA as a template was carried out with Taq DNA polymerase (NEB, Ipswich, MA, USA) with primers introducing suitable restriction sites (Biomers, Ulm, Germany) and under PCR conditions summarized in Table 1.
PCR products and the pGL3-Basic plasmid were digested with the appropriate restriction enzymes, ligated, and transformed into Escherichia coli strain XL1-Blue using standard protocols (Sambrook \& Russell 2001). For site-directed mutagenesis of putative transcription factor-binding sites, the QuikChange II XL Kit (Stratagene, La Jolla, CA, USA) was used according to the manufacturer's recommendations. The sequences of all the constructs were verified by dye-terminator sequencing (Jenagen, Jena, Germany). Plasmid preparations for transfection were obtained using the PureYield Plasmid Midiprep System (Promega).

\section{Reporter gene assays}

To quantify promoter activities, the pGL3-Basic plasmid was used, where the firefly luciferase is under the control of the promoter sequence cloned upstream of the reporter gene. The 3T3-L1 cells in 24-well plates were co-transfected with $800 \mathrm{ng}$ of pGL3-Basic constructs and with $50 \mathrm{ng}$ of the pRL-TK vector expressing renilla luciferase under the control of the herpes simplex virus thymidine kinase promoter. The latter was used to normalize results for differences in transfection efficiencies. Liposome-mediated transfection was carried out using the Roti-Fect transfection reagent according to the manufacturer's instructions (Roth, Karlsruhe, Germany). Twenty-four hours later, the cells were carefully washed free from growth medium containing FCS with a serum-free medium and incubated for $8 \mathrm{~h}$ with a serum-free medium containing retinoids $(1 \mu \mathrm{M})$ or a vehicle. Subsequently, the monolayers were washed with PBS, and the cells were lysed with passive lysis buffer. Firefly and renilla luciferase activities in the lysates were measured using the Dual Luciferase Reporter Assay System (Promega) on a Mithras instrument (Berthold Technologies, Bad Wildbad, Germany). Test readings for both luciferases were corrected for respective background readings. The data reported herein were calculated as corrected firefly luciferase/corrected renilla luciferase for each individual well. Three replicate wells per experimental condition were tested in each experiment.

\section{Cell fractionation and electrophoretic mobility shift assays}

To test for factors binding to the putative transcription factor-binding site, electrophoretic mobility shift assays (EMSAs) were carried out essentially as described previously (Taylor et al. 1994), with some modifications: induced cells ( $8 \mathrm{~h}$ if not indicated otherwise) were washed and scraped from $10 \mathrm{~cm}$ culture dishes, transferred into a $15 \mathrm{ml}$

Published by Bioscientifica Ltd. 
Table 1 Primers and conditions for PCR amplification and mutagenesis. Primers for the generation of promoter constructs are indicated by the respective promoter names, and primers for mutagenesis are indicated by the mutated site, which is given in bold letters. Cycling conditions used for the generation of the respective constructs are indicated by times and temperatures for each step and number of cycles

\begin{tabular}{|c|c|}
\hline $\begin{array}{l}\text { Promoter } \\
\text { construct/ } \\
\text { mutated site }\end{array}$ & Primer sequences \\
\hline PI.3 & $\begin{array}{l}\text { F: 5'-ATGGTACCTTCCTGAGTGGCACCTGAGC } \\
\text { R: 5'-ATCCCGGGAAAGCCAAATTTCTTGCCA }\end{array}$ \\
\hline PI.6 & $\begin{array}{l}\text { F: 5'-ATGGTACCGCTTGTCATCAACAAAGGAA } \\
\text { R: 5'-ATCCCGGGTAGTCTGTAGCTGAAGAG }\end{array}$ \\
\hline PI.7 & $\begin{array}{l}\text { F: 5'-CATGCTAGCAGGCCCTGAGCTCTGGAAGC } \\
\text { R; 5'-GCATCTCGAGTCTCCGGTCTTACTT- } \\
\text { CATCCTTGTAG }\end{array}$ \\
\hline PII & $\begin{array}{l}\text { F: 5'-ATGGTACCTGAAGTCACTAGAGATG } \\
\text { R: 5'-ATCCCGGGCTGTACAGTACAGATTCACT }\end{array}$ \\
\hline PI.4(-565/+211) & $\begin{array}{l}\text { F: 5'-ATGCTAGCGCTTAGGCTAAGCTGAATAT } \\
\text { R: 5'-ATCTCGAGTGGTCACGTTCTACTTGGAG }\end{array}$ \\
\hline $\mathrm{PI} .4(-256 /+211)$ & F: 5'-ATGCTAGCTGTATGGTCAGCTTGGGGAA \\
\hline PI.4(-161/+211) & F: 5'-ATGGTACCACTCAACTTTCCAAATGCTGGT \\
\hline PI.4(-89/+211) & F: 5'-ATGGTACCAGCTCGATTCATAATGAATGCA \\
\hline $\begin{array}{l}\text { PI.4(+24/+211) } \\
\text { PI.4(+124/+211) }\end{array}$ & $\begin{array}{l}\text { F: 5'-ATGGTACCCTAGATTGGGAAAACTCTGA } \\
\text { F: 5'-ATGGTACCAGGAGATCCCTGAATGT }\end{array}$ \\
\hline RARE1a & $\begin{array}{l}\text { F: 5'-CGCGTGCTAGCTGTATGGAAAGCTTGGG- } \\
\text { GAAATATGTG } \\
\text { R: 5'-CACATATTTCCCCAAGCTTTCCATACAGC- } \\
\text { TAGCACGCG }\end{array}$ \\
\hline RARE1b & $\begin{array}{c}\text { F: } 5^{\prime} \text {-CATACCACATTATGATTGGAAAGATGCA- } \\
\text { CATTGAATTTCCGACAAAATGAAACTC } \\
\text { R: 5'-GAGTTTCATTTTGTCGGAAATTCAATGTG- } \\
\text { CATCTTTCCAATAATGTGGTATG }\end{array}$ \\
\hline RARE2 & $\begin{array}{l}\text { F: } 5^{\prime} \text {-GTCCCAGGAAGATTGAGAACACAGAAGG- } \\
\text { CAGAGGCC } \\
\text { R: } 5^{\prime} \text {-GGCCTCTGCCTTCTGTGTTCTCAATCTT } \\
\text { CCTGGGAC }\end{array}$ \\
\hline RARE3 & $\begin{array}{l}\text { F: } 5^{\prime} \text {-CAGGAGATCCCTGTTCCATGTGGGAA- } \\
\text { CATGGGCGGGGCA } \\
\text { R: } 5^{\prime} \text {-TGCCCCGCCCATGTTCCCACATGGAACAGG- } \\
\text { GATCTCCTG }\end{array}$ \\
\hline SP1 & $\begin{array}{l}\text { F: } 5^{\prime} \text {-GGGAAAACTCTGACACCCCTAACCCATGAC- } \\
\text { CAACCAAG } \\
\text { R: 5'-GGTTGGTCATGGGTTAGGGGTGTCA- } \\
\text { GAGTTTTCCC }\end{array}$ \\
\hline RARE2 re-mut & 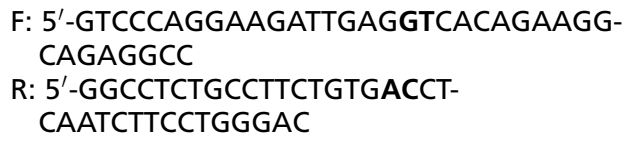 \\
\hline
\end{tabular}

\begin{tabular}{|c|c|c|c|c|}
\hline $\begin{array}{l}\text { Restriction } \\
\text { site }\end{array}$ & Denaturation & Annealing & Elongation & Cycles \\
\hline $\begin{array}{l}\text { Kpnl } \\
\text { Smal }\end{array}$ & $30 \mathrm{~s} / 94^{\circ} \mathrm{C}$ & $120 \mathrm{~s} / 48^{\circ} \mathrm{C}$ & $180 \mathrm{~s} / 72{ }^{\circ} \mathrm{C}$ & 40 \\
\hline $\begin{array}{l}\text { Kpnl } \\
\text { Smal }\end{array}$ & $30 \mathrm{~s} / 94^{\circ} \mathrm{C}$ & $120 \mathrm{~s} / 46^{\circ} \mathrm{C}$ & $180 \mathrm{~s} / 72^{\circ} \mathrm{C}$ & 40 \\
\hline $\begin{array}{l}\text { Nhel } \\
\text { Xhol }\end{array}$ & $20 \mathrm{~s} / 98^{\circ} \mathrm{C}$ & $20 \mathrm{~s} / 62^{\circ} \mathrm{C}$ & $30 \mathrm{~s} / 72{ }^{\circ} \mathrm{C}$ & 40 \\
\hline $\begin{array}{l}\text { Kpnl } \\
\text { Smal }\end{array}$ & $30 \mathrm{~s} / 94^{\circ} \mathrm{C}$ & $120 \mathrm{~s} / 57^{\circ} \mathrm{C}$ & $180 \mathrm{~s} / 72{ }^{\circ} \mathrm{C}$ & 40 \\
\hline $\begin{array}{l}\text { Nhel } \\
\text { Xhol }\end{array}$ & $30 \mathrm{~s} / 94^{\circ} \mathrm{C}$ & $60 \mathrm{~s} / 55^{\circ} \mathrm{C}$ & $120 \mathrm{~s} / 72{ }^{\circ} \mathrm{C}$ & 40 \\
\hline Nhel & $30 \mathrm{~s} / 94^{\circ} \mathrm{C}$ & $60 \mathrm{~s} / 55^{\circ} \mathrm{C}$ & $120 \mathrm{~s} / 72{ }^{\circ} \mathrm{C}$ & 40 \\
\hline Kpnl & $30 \mathrm{~s} / 94^{\circ} \mathrm{C}$ & $120 \mathrm{~s} / 55^{\circ} \mathrm{C}$ & $180 \mathrm{~s} / 72{ }^{\circ} \mathrm{C}$ & 40 \\
\hline Kpnl & $30 \mathrm{~s} / 94^{\circ} \mathrm{C}$ & $120 \mathrm{~s} / 54^{\circ} \mathrm{C}$ & $180 \mathrm{~s} / 72{ }^{\circ} \mathrm{C}$ & 40 \\
\hline Kpnl & $30 \mathrm{~s} / 94^{\circ} \mathrm{C}$ & $60 \mathrm{~s} / 44^{\circ} \mathrm{C}$ & $60 \mathrm{~s} / 72{ }^{\circ} \mathrm{C}$ & 30 \\
\hline \multirow[t]{7}{*}{ Kpnl } & $30 \mathrm{~s} / 94^{\circ} \mathrm{C}$ & $60 \mathrm{~s} / 48^{\circ} \mathrm{C}$ & $60 \mathrm{~s} / 72^{\circ} \mathrm{C}$ & 30 \\
\hline & $50 \mathrm{~s} / 95^{\circ} \mathrm{C}$ & $50 \mathrm{~s} / 60^{\circ} \mathrm{C}$ & $317 \mathrm{~s} / 68^{\circ} \mathrm{C}$ & 18 \\
\hline & $50 \mathrm{~s} / 95^{\circ} \mathrm{C}$ & $50 \mathrm{~s} / 60^{\circ} \mathrm{C}$ & $317 \mathrm{~s} / 68^{\circ} \mathrm{C}$ & 18 \\
\hline & $50 \mathrm{~s} / 95^{\circ} \mathrm{C}$ & $50 \mathrm{~s} / 60^{\circ} \mathrm{C}$ & $317 \mathrm{~s} / 68^{\circ} \mathrm{C}$ & 18 \\
\hline & $50 \mathrm{~s} / 95^{\circ} \mathrm{C}$ & $50 \mathrm{~s} / 60^{\circ} \mathrm{C}$ & $317 \mathrm{~s} / 68^{\circ} \mathrm{C}$ & 18 \\
\hline & $50 \mathrm{~s} / 95^{\circ} \mathrm{C}$ & $50 \mathrm{~s} / 60^{\circ} \mathrm{C}$ & $317 \mathrm{~s} / 68^{\circ} \mathrm{C}$ & 18 \\
\hline & $50 \mathrm{~s} / 95^{\circ} \mathrm{C}$ & $50 \mathrm{~s} / 60^{\circ} \mathrm{C}$ & $317 \mathrm{~s} / 68^{\circ} \mathrm{C}$ & 18 \\
\hline
\end{tabular}

polypropylene tube, and centrifuged for $3 \mathrm{~min}$ at $3000 \mathrm{~g}$. The pellet was resuspended in $1.2 \mathrm{ml}$ PBS and centrifuged for $2 \mathrm{~min}$ at $1530 \mathrm{~g}$. Then, the pellet was resuspended in $400 \mu \mathrm{l}$ Buffer A (10 mM HEPES, pH 7.9, containing $10 \mathrm{mM} \mathrm{KCl,}$ $0.1 \mathrm{mM}$ EDTA, $0.1 \mathrm{mM}$ EGTA, $1 \mathrm{mM}$ dithiothreitol (DTT), and $0.5 \mathrm{mM}$ phenylmethylsulphonyl fluoride (PMSF)). The cells were allowed to swell on ice for $15 \mathrm{~min}$. Then, $25 \mu \mathrm{l}$ of $10 \%(\mathrm{v} / \mathrm{v})$ Triton X-100 solution were added. After centrifugation for $2 \mathrm{~min}$ at $1530 \mathrm{~g}$, the supernatant was considered as the cytosolic fraction. The pellet was resuspended in $50 \mu \mathrm{l}$
Buffer C (20 mM HEPES, pH 7.9, containing $400 \mathrm{mM} \mathrm{NaCl}$, 1 mMEDTA, 1 mM EGTA, 1 mM DTT, and 1 mM PMSF) and shaken for $20 \mathrm{~min}$ at $4{ }^{\circ} \mathrm{C}$. The supernatant obtained after centrifugation for $5 \mathrm{~min}$ at $20800 \mathrm{~g}$ was considered as the soluble nuclear extract. The protein concentration of the fractions was quantified using the Bradford method (Bradford 1976). Both fractions were aliquoted and stored at $-80^{\circ} \mathrm{C}$ until further analysis. For EMSAs, $20 \mu \mathrm{g}$ of protein per condition were incubated in the presence of $250 \mathrm{ng}$ poly$\mathrm{dI} / \mathrm{dC}$ for $30 \mathrm{~min}$ at $37^{\circ} \mathrm{C}$ with various double-stranded

Published by Bioscientifica Ltd 
probes: 25 pmol of a Cy5-labeled RARE2 probe (5'-AAG ATT GAG GTC ACA GAA GGC AGA GGCC), either alone or in the presence of a 100-fold molar excess of an unlabeled RARE2 probe (competitor), or with 25 pmol of a Cy5-labeled mutated RARE2 probe (5'-AAG ATT GAG AAC ACA GAT AAC AGA GGCC). For antibody competition, $200 \mathrm{ng}$ of anti-RAR $\alpha$ antibodies were incubated with nuclear extracts for $30 \mathrm{~min}$ on ice before the addition of probes. Separations were carried out on a $6 \%$ nondenaturing acrylamide gel at $4{ }^{\circ} \mathrm{C}(18 \mathrm{~cm}, 300 \mathrm{~V}$, and $80 \mathrm{~min}$; Taylor et al. 1994). The wet gels were directly scanned on a Fuji FLA-3000 imaging system and quantified using the AIDA Software (Raytest, Straubenhardt, Germany).

\section{Western blotting}

Two percent of the total protein of cytosolic and nuclear fractions (see above) was separated on 10\% SDSpolyacrylamide gels (Laemmli 1970) and subsequently transferred onto PVDF membranes using semi-dry blotting at $0.8 \mathrm{~mA} / \mathrm{cm}^{2}$ of membrane for $60 \mathrm{~min}$. After blocking in $5 \%(\mathrm{w} / \mathrm{v})$ nonfat dry milk, the membranes were incubated with primary antibodies for $60 \mathrm{~min}$ at room temperature followed by incubation with an appropriate HRPconjugated secondary antibody. As the primary antibodies rabbit anti-RAR $\alpha$ (C-20), goat anti-RAR $\beta$ (C-19), and mouse anti-RAR $\gamma$ (G-1) were used at a dilution of 1:1000, HRPconjugated preadsorbed secondary antibodies goat anti-mouse IgG, goat anti-rabbit IgG, and rabbit anti-goat IgG were used at a dilution of 1:5000 (all antibodies were obtained from Santa Cruz). In addition, mouse anti-Lamin A/C (BD 612162, 1:1000, BD Biosciences, Heidelberg, Germany) and mouse anti-GAPDH (MAB374, 1:20 000, Merck Millipore, Darmstadt, Germany) were used. Proteins were detected using enhanced chemiluminescence (PerkinElmer, Rodgau-Jügesheim, Germany) and quantified using the AIDA Software.

\section{Immunofluorescence microscopy}

The 3T3-L1 cells were cultured on collagen-coated cover slides, incubated with a serum-free medium overnight, and fixed with $4 \%$ formaldehyde. The slides were blocked and permeabilized with PBS/Triton X-100 and then incubated with primary antibodies (see above) at $4{ }^{\circ} \mathrm{C}$ overnight at a dilution of 1:1000. For detection, preadsorbed Cy3-labeled antibodies against the various primary antibodies were used (goat anti-rabbit for RAR $\alpha$, donkey anti-goat for RAR $\beta$ (RARB), and goat anti-mouse for RAR $\gamma$ (RARG); 1:600 each).

\section{Chromatin immunoprecipitation}

Chromatin immunoprecipitation (ChIP) analysis was carried out essentially as described previously (Weiske \& Huber 2006). BAFs from four $10 \mathrm{~cm}$ dishes per condition were used. For immunoprecipitation, RAR antibodies or anti-TATA-box-binding protein (TBP; TFIID) antibodies (N-12, Santa Cruz) were used at $1 \mu \mathrm{g} /$ reaction. For PCR analysis, $2 \mu \mathrm{l}$ of the extracted DNA were used as a template for 37 cycles of amplification. Primers for amplification of a 145 bp promoter I. 4 fragment were $5^{\prime}$-TCC CAG GAA ACA GCC CTC TGGA (forward) and 5'-CTC CTG GAG AGG GGG CAG GC (reverse). PCR products were analyzed on $12 \%(\mathrm{wt} / \mathrm{vol})$ polyacrylamide gels.

\section{Software and statistical analyses}

For sequence verification, the BLAST Software was used (up to version 2.2.22+; Altschul et al. 1997). Searches for putative transcription factor-binding sites were carried out using the MatInspector Software (up to version 8.0., Genomatix (München, Germany); Cartharius et al. 2005). Differences between the treatment groups were identified using two-sided Student's $t$-test. When data within at least one treatment group were not normally distributed, the Mann-Whitney rank sum test was used for all the comparisons of data obtained from that experiment. Differences were considered significant when $P<0.05$. All the analyses were carried out using the SigmaPlot Software (Systat, Erkrath, Germany).

\section{Results}

As retinoids are readily available within adipose tissue, we hypothesized that bioactive retinoids might be involved in the regulation of aromatase expression in human BAFs. To directly test this hypothesis, we assayed human BAFs isolated from subcutaneous adipose tissue for aromatase activity induction by at-RA and 9cis-RA. There was a significant five- to sixfold induction of aromatase activity by both retinoids (Fig. 1A). This was paralleled by a significant increase in the expression of the full-length aromatase mRNA in at-RA-stimulated cells (Fig. 1B). Aromatase expression was driven time dependently by promoter I.4 usage (Fig. 1B and C). There was no significant effect of at-RA on the transcripts containing exons I.3 and II.

To get insight into the mechanism underlying the retinoid-mediated induction of aromatase activity, a panel of reporter gene constructs was generated. The promoter regions of the human aromatase gene, which are known to

Published by Bioscientifica Ltd. 

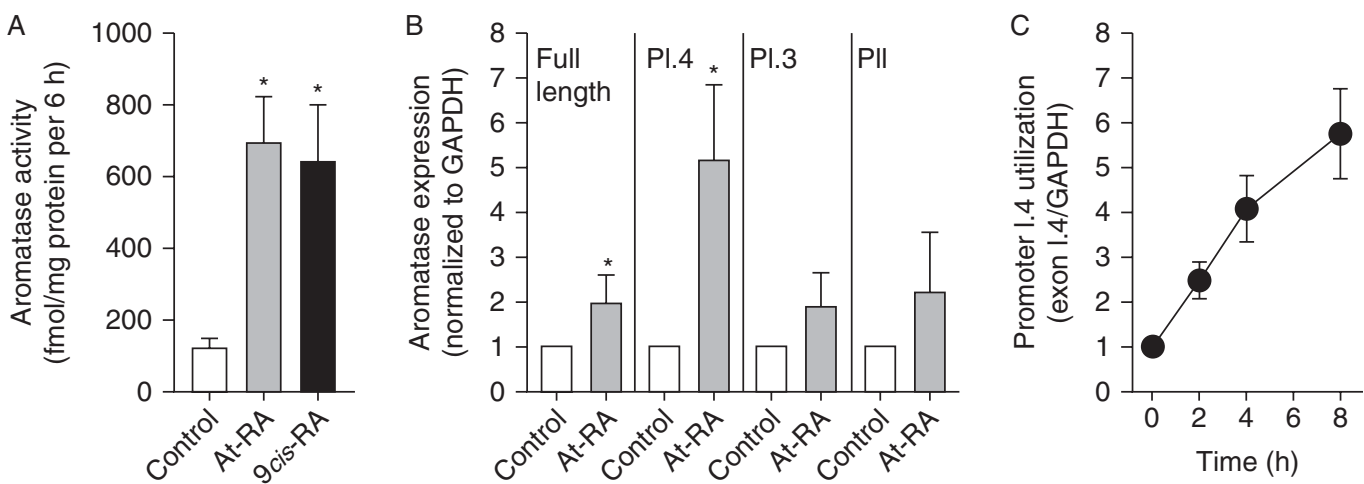

\section{Figure 1}

Retinoids induce aromatase activity via promoter I.4. Human BAFs were isolated and cultured as described in the Materials and methods section. Aromatase activity was induced under serum-free conditions using a vehicle alone (control), $1 \mu \mathrm{M}$ at-RA, or $1 \mu \mathrm{M} 9$ cis-RA. This concentration ensures maximum effects in various retinoid receptor-dependent assays (Kiefer et al. 2012). (A) Aromatase activity was measured after $24 \mathrm{~h}$ using the ${ }^{3} \mathrm{H}-\mathrm{H}_{2} \mathrm{O}$ release assay. Data are presented as means \pm s.E.M. from three preparations of cells, which were tested in triplicates each. (B) Aromatase

be involved in the regulation of aromatase expression in BAFs by a variety of hormonal factors, were cloned into the pGL3-Basic vector (for an overview, see Table 1), where firefly luciferase expression is under the control of the native promoter fragment. To identify the aromatase promoter involved in retinoid-mediated induction, murine 3T3-L1 cells, which represent a proven model system to study regulators of aromatase activity induction, were used (Rubin et al. 2000, Clyne et al. 2002). The pGL3-Basic promoter constructs were transiently transfected into these cells. Twenty-four hours after transfection, the cells were exposed to retinoids for $8 \mathrm{~h}$ in the absence of serum and subsequently tested for reporter gene activity. There was no retinoid-dependent induction of reporter gene activity when aromatase promoters PI.3, PI.6, and PII were tested (Fig. 2A). In addition, we found no effect of retinoids on a construct containing a functional fragment of promoter I.7 (Fig. 2B). However, both at-RA and 9cis-RA strongly induced reporter gene activity when a 776 bp region $(-565 /+211)$ of the human aromatase promoter PI.4 was tested (Student's $t$-test, $P<0.002$ ) (Fig. 2C).

Therefore, a series of constructs containing shortened fragments of promoter PI.4 was generated (Fig. 3B). A 467 bp region of PI.4 $(-256 /+211)$ is necessary for the retinoid-mediated induction of reporter activity (Fig. 2C). Shorter fragments were not inducible by retinoids, but they still exhibited significantly higher basal activity down to a length of $188 \mathrm{bp}(+24 /+211)$ than the shortest fragment $(+124 /+211)$
mRNA was measured using qPCR as described in the Materials and methods section. Relative expression levels from four experiments (means \pm s.E.M.) were calculated using the $\Delta \Delta C$ t method. PI.4, PI.3, and PII refer to untranslated first exons of transcripts, which indicate the usage of the respective promoters. ( $A$ and $B$ ) Significant differences vs controls were identified using Student's $t$-test $\left({ }^{*} P<0.05\right)$. (C) Time course of aromatase promoter I.4-containing transcript induction by at-RA. Data were obtained from two experiments \pm range.

An in silico analysis of the $467 \mathrm{bp}$ sequence using the MatInspector Software revealed four putative RXR heterodimer-binding sites with matrix similarities between 0.792 and 0.898 , which we considered as potential retinoic acid response elements (RAREs; Fig. 3A). To identify the responsive element(s) necessary for retinoid-mediated induction, the four putative response elements were individually inactivated by sitedirected mutagenesis in the pGL3-Basic-467 constructs (Fig. 3A and B). In addition, a SP1 element was mutated as a control.

Surprisingly, mutagenesis of the most promising candidates RARE1a and RARE1b, which are located in the $5^{\prime}$-end of the $467 \mathrm{bp}$ sequence, did not have any effect on retinoid responsiveness of the pGL3-Basic- $(-256 /+211)$ construct in reporter gene assays (Fig. 3C). The destruction of the most proximal RARE3 and the SP1 element also did not have any effect. However, mutagenesis of RARE2 led to a complete loss of the retinoid-dependent induction of reporter gene activity (Fig. 3C). The restoration of the WT sequence from the mutated construct by site-directed mutagenesis led to the complete restoration of retinoid responsiveness, indicating that specifically RARE2 mutation was responsible for the loss of retinoid effect (Fig. 3D). The MatInspector Software classified RARE2 as a VDR/RXR response element. Therefore, we tested whether $1,25(\mathrm{OH})_{2}$-vitamin D3 could induce reporter gene activity. There was no significant induction in comparison with ethanol-treated controls

Published by Bioscientifica Ltd. 
A

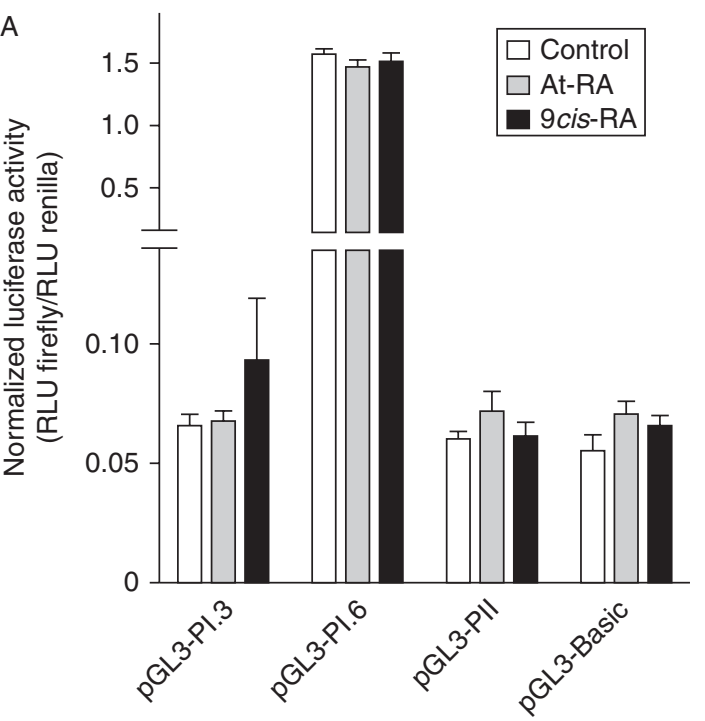

C

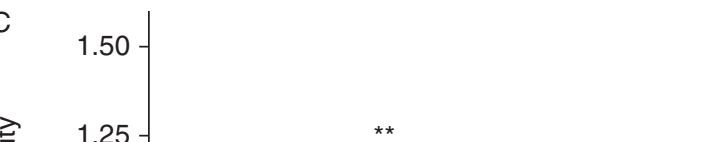

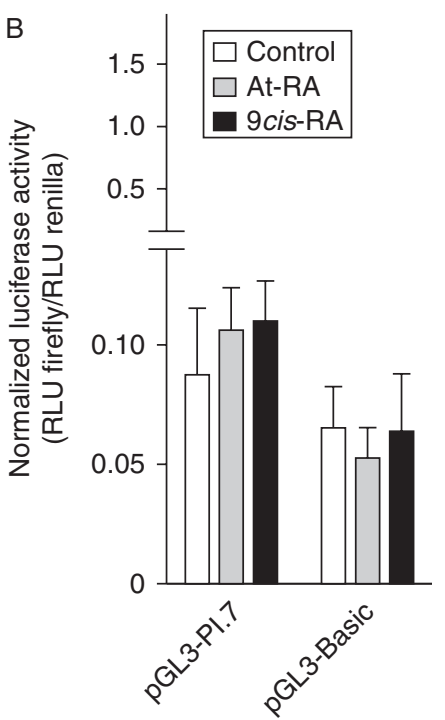

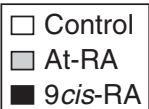

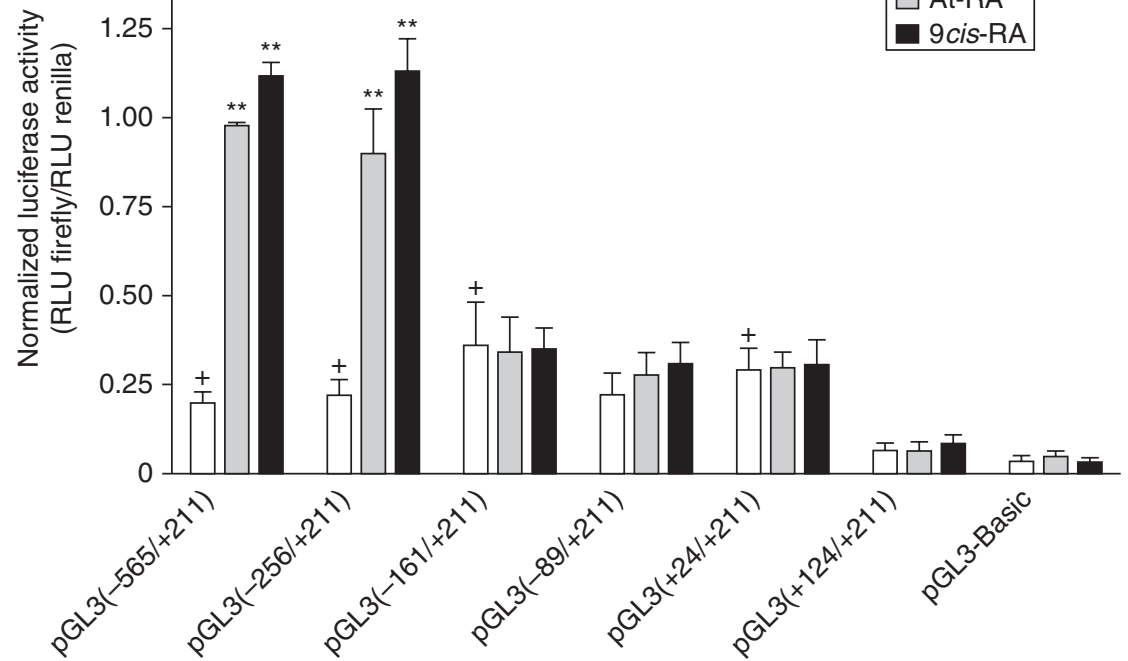

Figure 2

Retinoids selectively activate promoter PI.4. 3T3-L1 cells were transiently transfected with pGL3-Basic firefly luciferase reporter plasmids, where luciferase expression is under the control of the human aromatase promoter PI.3, PI.4, PI.6, PI.7, or PII. Promoter activities were tested using a dual luciferase assay, and results were normalized to the activities of the renilla luciferase, which was constitutively expressed from the co-transfected pRL-TK plasmid. Reporter gene expression was induced under serum-free conditions for $8 \mathrm{~h}$ with a vehicle alone (control), $1 \mu \mathrm{M}$ at-RA, or $1 \mu \mathrm{M}$ 9cis-RA. (A) Retinoids do not induce reporter gene expression under the control of promoters PI.3, PI.6, and PII. Means \pm s.E.M. of one representative experiment with triplicates are reported. Two additional

(which were set to $100 \pm 16 \%$, means \pm s.D., three experiments): reporter activity was $144 \pm 29,98 \pm 40$, and $128 \pm 11 \%$ for the fragments $(-565 /+211),(-256 /+211)$, and $(+24 /+211)$ respectively. experiments carried out using another instrument gave similar results. (B) Retinoids do not induce reporter gene expression under the control of promoter PI.7. Means \pm s.E.M. of triplicates are reported. (C) Reporter gene activity was induced by at-RA and 9cis-RA when pGL3-Basic plasmids containing $776 \mathrm{bp}(-565 /+211)$ and $467 \mathrm{bp}(-256 /+211)$ fragments of promoter PI.4 were transfected. Shorter fragments $(-161 /+211)$,

$(-89 /+211),(+24 /+211)$, and $(+124 /+211)$ did not respond to retinoid stimulation. Data are means + s.E.M. from three to six experiments with triplicates each. Significant differences vs the respective controls were identified using Student's $t$-test $(* * P<0.002) .(+P<0.05)$ indicates significant differences vs the control values for $\operatorname{pGL} 3(+124 /+211)$.

Both retinoids, at-RA and 9cis-RA, induced similar levels of reporter gene activity. Therefore, it was likely that a member of the RAR subfamily of nuclear receptors is involved. To obtain information about the expression of

Published by Bioscientifica Ltd 


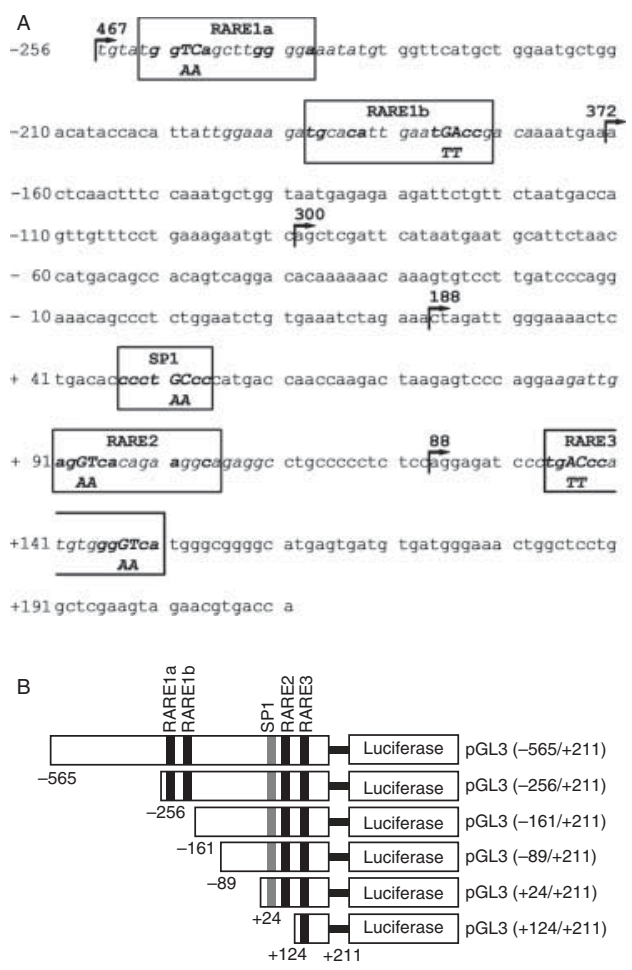

\section{Figure 3}

RARE2 is essential for the induction by retinoids. (A) Organization of the proximal $467 \mathrm{bp}$ fragment of PI.4. Kinked arrows indicate the $5^{\prime}$-ends of shorter promoter constructs; their lengths are given above the arrows. Nucleotides are numbered in relation to the start of the transcription of exon I.4 (+1). Italics indicate putative transcription factor-binding sites identified by the MatInspector Software tool from Genomatix. Boxes indicate core sequences of putative retinoic acid response elements RARE1a, RARE1b, RARE2, and RARE3 and the putative SP1 element, which was used in the control experiments. Full identity with the respective consensus sequences is indicated by bold types. The bases from the consensus sequences, which were mutated, are indicated by capital letters, and the replacements are given below in capital letters. (B) Schematic representation of the $\mathrm{pGL}$-Basic luciferase reporter constructs indicating the positions of the putative response elements mentioned above.

the RAR isoforms at the protein level, immunofluorescence microscopy and western blotting experiments were carried out. In the 3T3-L1 preadipocytes, only RAR $\alpha$ was readily detectable in immunofluorescence images, but no unequivocal RAR $\beta$ or RAR $\gamma$ staining could be detected (Supplementary Figure $1 \mathrm{~A}$, see section on supplementary data given at the end of this article). Western blotting confirmed these results, with anti-RAR $\alpha$ antibodies leading to strong signals within seconds of the chemiluminescence detection reactions, whereas the RAR $\beta$ - or RAR $\gamma$-specific antibodies yielded no specific signals (even after exposures of the films for more than $1 \mathrm{~h}$; Supplementary Figure 1B). Using very high concentrations of antibodies, however, weak signals Printed in Great Britain
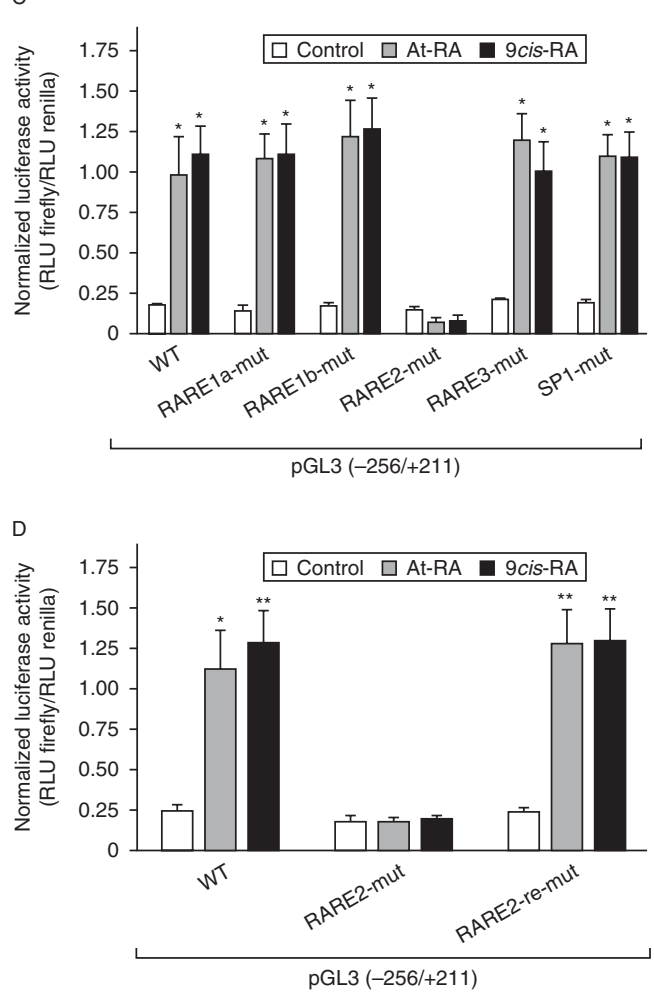

Subscript numbers indicate positions in relation to the transcriptional start site. The names of the constructs are given on the right side. (C) Highly conserved bases of the putative transcription factor-binding sites in the pGL3 $(-256 /+211)$ construct were mutated as indicated by their respective name and the extension -mut. The cells were lysed for dual luciferase assay after $8 \mathrm{~h}$ of induction by at-RA, 9cis-RA, and a vehicle alone (control), with triplicates for each condition in each experiment. Only the mutation of RARE2 abolished retinoid responsiveness in the $467 \mathrm{bp}$ construct pGL3(-256/+211). Significant differences vs controls were identified using the Mann-Whitney $U$ test $(n=4 ; * P<0.05)$. (D) Retinoid responsiveness of pGL3(-256/+211)-RARE2-mut was restored when its RARE2 was re-mutated into the WT sequence. Significant differences vs the respective controls were identified using Student's $t$-test $(n=3$; $* P<0.05$ and $* * P<0.01$ )

for RAR $\beta$ and RAR $\gamma$ could be detected in the 3T3-L1 cells (Supplementary Figure 2). Moreover, even under retinoid stimulation, RAR $\alpha$ expression in 3T3-L1 cells did not change significantly during $24 \mathrm{~h}$. Under the same conditions, RAR $\beta$ or $\operatorname{RAR} \gamma$ were not readily detectable (Supplementary Figure 1B).

From these observations, we concluded that RAR $\alpha$ is the candidate receptor mediating the retinoid-dependent effects on aromatase activity induction in human BAFs and reporter gene activity induction in 3T3-L1 cells. To further confirm the roles of RARE2 and RAR $\alpha$ in these retinoid-induced effects, cytosolic and nuclear extracts from unstimulated and retinoid-stimulated cells were

Published by Bioscientifica Lto. 
prepared. In a first series of experiments, the localization of RARs with and without retinoid stimulation was analyzed. There was no significant difference in RAR $\alpha$ accumulation in the nuclear fractions of unstimulated and retinoid-stimulated 3T3-L1 cells (Supplementary Figure $3 \mathrm{~A}$, see section on supplementary data given at the end of this article) and human BAFs respectively (Supplementary Figure 3B). In these experiments, again only $\operatorname{RAR} \alpha$ was readily detectable. The quality of extracts was assessed by detection of GAPDH as a cytosolic marker and Lamin $\mathrm{A} / \mathrm{C}$ as a nuclear marker (Supplementary Figure 3C).

To directly test the specific binding of transcription factors to RARE2, cytosolic and nuclear extracts were tested in EMSAs with fluorescently labeled probes. There was no specific binding when cytosolic extracts were used in the binding reactions (data not shown). However, when the binding reactions were carried out with nuclear extracts obtained from unstimulated and retinoidstimulated 3T3-L1 cells, a specific complex binding to the labeled probe was identified (Fig. 4B). A 100-fold molar excess of unlabeled probe suppressed the detection of the complex almost completely. When nuclear extracts were used for the binding reactions with a labeled probe containing a mutated RARE2, complex formation was almost undetectable. To confirm the involvement of RAR $\alpha$, nuclear extracts were incubated with anti-RAR $\alpha$ antibodies before the addition of the WT RARE2 probe. Under these conditions, the specific complex was also almost undetectable (Fig. 4B), suggesting that antibody binding affects DNA binding of RAR $\alpha$. Taken together, RARE2 is incorporated into a specific complex containing RAR $\alpha$ under basal and retinoid-stimulated conditions in 3T3-L1 cells. Importantly, retinoid stimulation leads to an increased formation of a RARE2-binding complex (statistically significant in 9cis-RA-treated cells; Fig. 4A). Almost identical results were obtained for human BAFs. However, in these cells, two specific RARE2-binding complexes were detected (Fig. 4C).

ChIP analysis can detect protein-DNA interaction in vivo. Therefore, we carried out ChIP experiments using human BAFs, either mock-stimulated with ethanol or stimulated with at-RA. DNA-protein complexes were precipitated with the isoform-specific RAR antibodies or with a TBP antibody as a nonspecific control. Treatment with at-RA led to a significant increase in the amounts of the RARE2-containing promoter I.4 amplicon in the immunoprecipitates obtained with $\operatorname{RAR} \alpha$ antibodies. This indicates that at-RA induced the binding of RAR $\alpha$ to RARE2 in BAFs (Fig. 5).
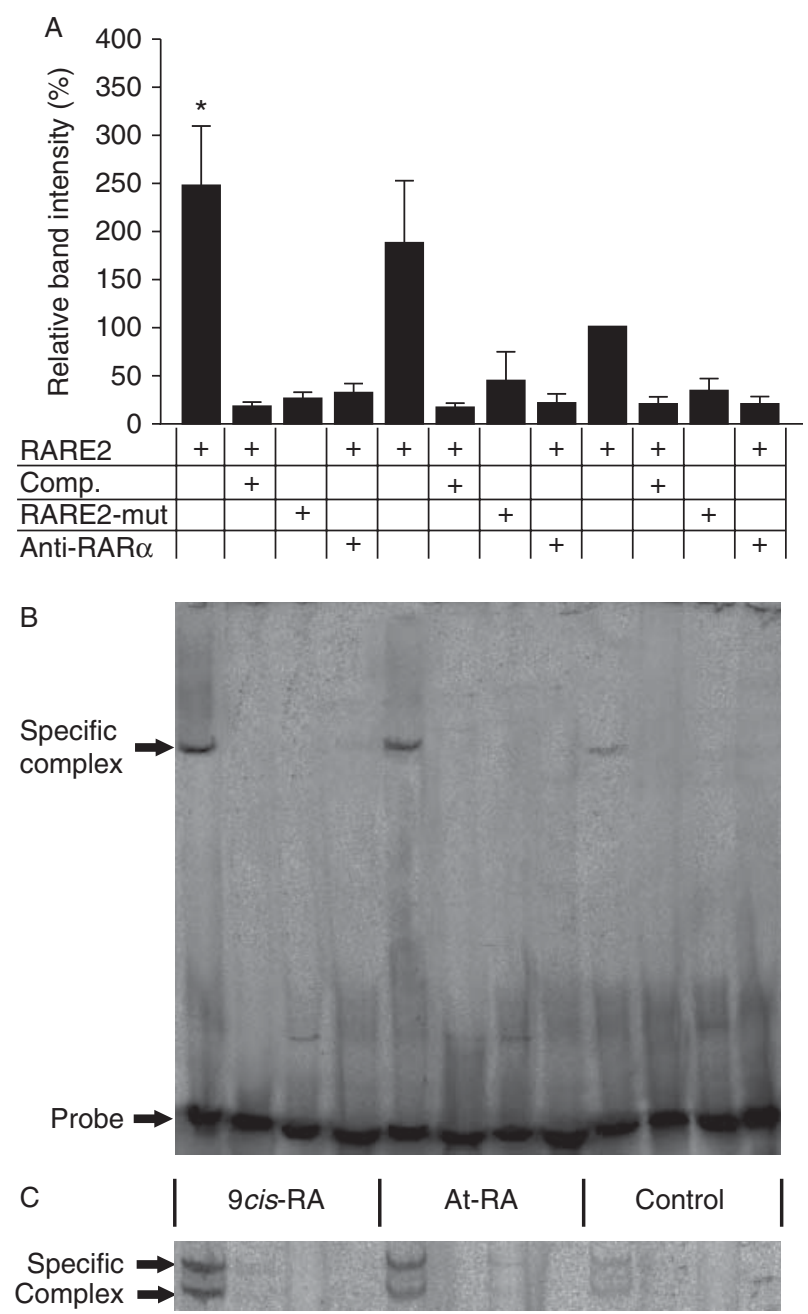

Figure 4

Retinoid-dependent binding of RAR $\alpha$ to RARE2 in preadipocytes. Electrophoretic mobility shift assays were carried out with nuclear extracts obtained from cells treated with at-RA, 9cis-RA, or a vehicle (control). Extracts were incubated with a Cy5-labeled RARE2 probe (RARE2) in the absence or presence of a 100-fold molar excess of an unlabeled RARE2 probe (Comp.) or with a labeled probe harboring the mutated RARE2 sequence (RARE2-mut). In addition, extracts were pre-incubated with $200 \mathrm{ng}$ anti-RAR $\alpha$ antibodies for $30 \mathrm{~min}$ before incubation with a labeled RARE2 probe. (A) Quantification of band intensities obtained in four EMSA experiments. Data were normalized to the amount of a specific complex found in control extracts incubated with a labeled RARE2 probe. Significant differences vs the corresponding controls were identified using the Mann-Whitney $U$ test $\left({ }^{*} P<0.05\right)$. (B) Fluorescence scan of the representative EMSAs carried out with 3T3-L1 extracts and (C) with human BAF extracts.

In the reporter gene assays with retinoid-stimulated cells, it was evident that the deletion of the RARE2containing region resulted in a significant reduction of basal promoter activity (see Fig. 2C). Whereas RARE2 was necessary but not sufficient for the retinoid-dependent induction of reporter activity, it was not clear whether this

Published by Bioscientifica Ltd 


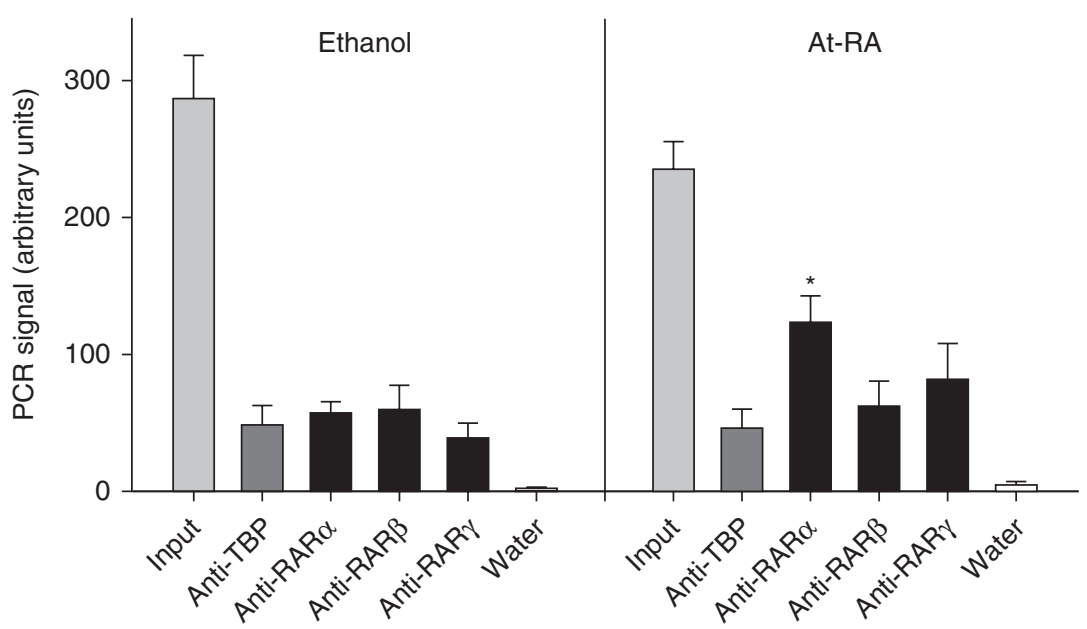

\section{Figure 5}

In vivo binding of RAR $\alpha$ to RARE2 in BAFs. Chromatin immunoprecipitation was carried out as described in the Materials and methods section using DNA-sheared lysates from control (ethanol) and at-RA-treated BAFs, which were harvested $8 \mathrm{~h}$ after stimulation. Precleared lysates were incubated with $1 \mu \mathrm{g}$ of each of the indicated antibodies. Phenol-chloroformextracted DNA was used as a template in PCR amplifications of a $145 \mathrm{bp}$ promoter I.4 amplicon, which was designed to exclude RARE1a, RARE1b,

element is involved in basal induction. Therefore, we repeated the analysis of the various promoter PI.4 constructs without any stimulation and in the presence of ethanol, which was used as a vehicle for all retinoid applications. The results summarized in Fig. $6 \mathrm{~A}$ clearly indicate that the $100 \mathrm{bp}$ fragment, which is lost in the shortest construct pGL3 $(+124 /+211)$ in comparison with the $188 \mathrm{bp}$ promoter construct pGL3 $(+24 /+211)$, is indispensable for basal induction.

To test whether RARE2 might be the element involved in basal induction, the putative $S P 1$ element, RARE2, and RARE3 were mutated in the pGL3 $(-89 /+211)$ promoter construct. Only site-directed inactivation of RARE2 resulted in a complete loss of basal promoter activity, whereas mutation of the SP1 site and RARE3 did not alter reporter activity (Fig. 6B). Taken together, these experiments indicate that RARE2 is essential for basal aromatase promoter PI.4 activity.

\section{Discussion}

Two major pathways of aromatase activity induction in human adipose tissue are well established: a glucocorticoid-dependent pathway targeting promoter I.4 is used in normal adipose tissue, whereas a cAMP-dependent pathway targeting promoter II is predominantly used in and RARE3. Band intensities were quantified with the AIDA Imaging Software (Raytest, Straubenhardt, Germany). TBP antibody was used as a nonspecific control. Input, 1:50 diluted DNA extracted from non-precipitated lysate; water, no-template control. PCR signals from at-RA-stimulated lysates immunoprecipitated with anti-RAR $\alpha$ antibodies significantly differed from signals obtained with all the other antibodies (five experiments; Student's $t$-test; ${ }^{*} P=0.011$ ).

adipose tissue in the vicinity of malignant breast tumors (Agarwal et al. 1996, Simpson 2004).

In this study, we identified a novel, retinoid-dependent mechanism for aromatase activity induction in human BAFs, showed that the factor(s) involved are also functional in mouse 3T3-L1 preadipocytes, and suggest that this mechanism is similarly active in human adipose tissue. Both physiologically relevant retinoids used in this study, at-RA and 9cis-RA, induce aromatase activity and mRNA expression in human BAFs under conditions of extensive serum depletion. Under these conditions, glucocorticoids also induce aromatase activity (Zhao et al. 1995a). A common feature of the retinoid pathway (shown in this study) and the glucocorticoid pathway is that they trigger the utilization of promoter I.4, but not that of other promoters found to be used in adipose tissue cells. The stimulation of both pathways results in similar levels of induction (data not shown), but the molecular mechanisms are different. Zhao et al. (1995a) have localized the glucocorticoid response element in promoter I. 4 at position $(-133 /-119)$, where the binding of the glucocorticoid receptor controls induction. This promoter region is not involved in retinoid-mediated induction, as outlined below.

To bring about strong aromatase activity induction, glucocorticoids depend on the presence of serum, which can be replaced by suitable cytokines, e.g. PDGF-BB, TNF $\alpha$ (TNF), or cytokines from the IL6 family (Schmidt \& Loffler

Published by Bioscientifica Ltd. 

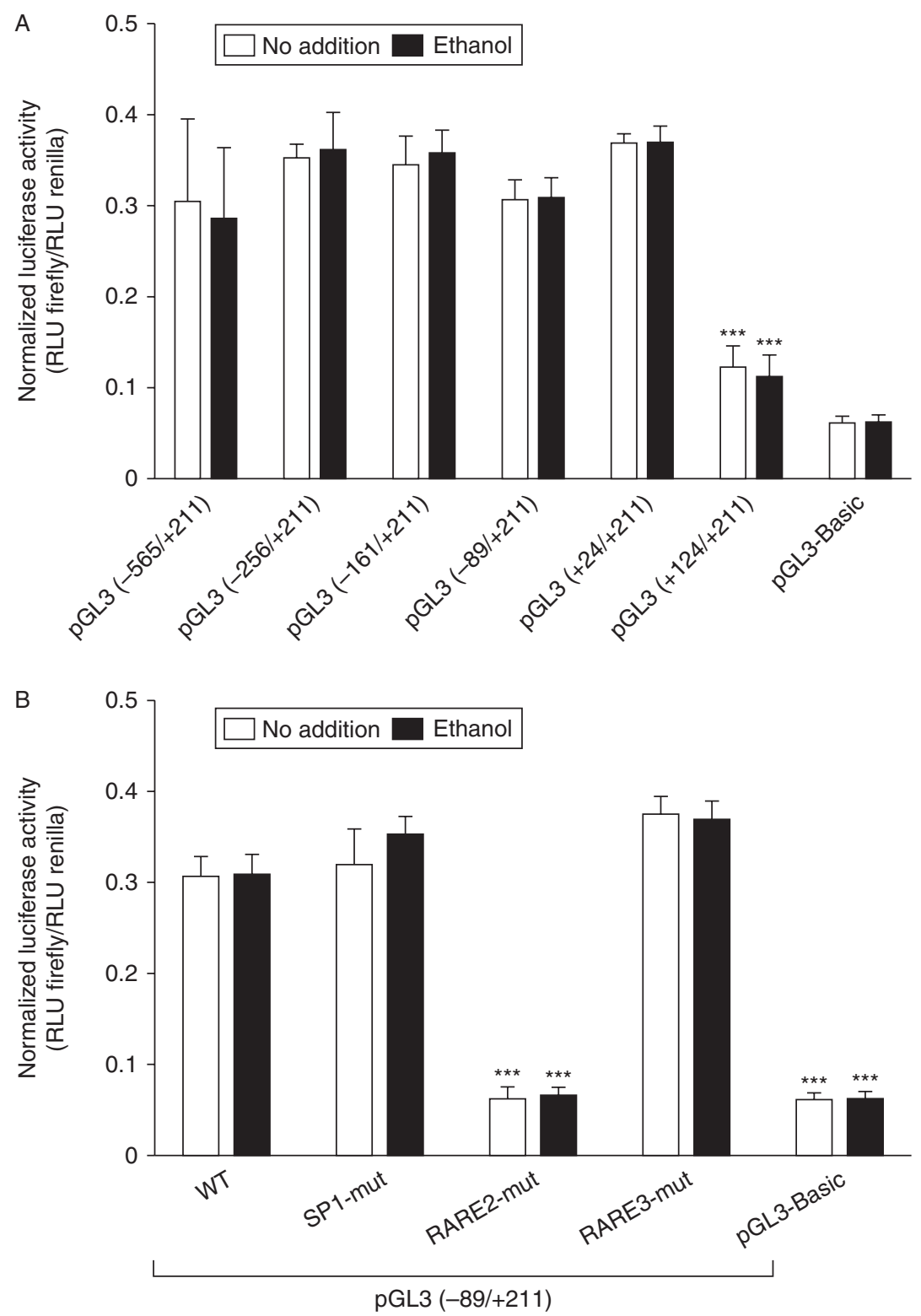

\section{Figure 6}

RARE2 but not the upstream sequence is essential for basal transcriptional activity of aromatase promoter I.4. (A) Reporter gene activity was measured in 3T3-L1 cells, which were transfected with pGL3-Basic constructs carrying promoter fragments from $776 \mathrm{bp}$ down to $88 \mathrm{bp}$ in length (length is given in the figure). The cells were either not treated or incubated for $8 \mathrm{~h}$ with only ethanol (which was used as a vehicle in all the experiments described above). Data are means \pm s.E.M. from three to five experiments with triplicates each. The loss of transcriptional activity of the $88 \mathrm{bp}$ fragment

1994, Zhao et al. 1995b, 1996b). These cytokines activate specific upstream response elements in promoter I.4 (see Chen et al. (2009) for a detailed overview). The most proximal of these binding sites, a GAS site at position $(-282 /-272)$, is activated by the IL6 family cytokines via binding of STAT3 (Zhao et al. 1995b). However, these
$(+124 /+211)$ in comparison with the longer fragments (188-776 bp) was highly significant (Student's $t$-test; $* * * P<0.001$ ). (B) $S P 1$, RARE2, and RARE3 were mutated in the pGL3 $(-89 /+211)$ promoter construct, basically as described in Fig. 3. The mutation of RARE2 led to a complete loss of the transcriptional activity of the 300 bp construct. Significant differences vs the WT construct PGL3 $(-89 /+211)$ were identified using Student's $t$-test $(n=4-5 ; * * * P<0.001)$

upstream binding sites are not relevant for basal retinoidmediated induction.

The retinoid-mediated activation of aromatase promoter I.4 was analyzed in detail using a luciferase reporter system and site-directed mutagenesis. A $467 \mathrm{bp}$ fragment $(-256 /+211)$ of the human promoter sequence

Published by Bioscientifica Ltd. 
is sufficient to drive the retinoid-induced expression of the luciferase reporter gene. On this promoter fragment, four putative RAREs were identified in silico. However, the experimental evidence described above clearly assigns a role for the retinoid-mediated induction of the reporter only to RARE2 $(+91 /+105)$. Data base analysis using the MatInspector Software classified RARE2 as a VDR/RXR response element, containing a three-base pair spacer (a DR3 element). To directly test this, reporter gene assays were repeated with $1,25(\mathrm{OH})_{2}$-vitamin D3. However, this hormone did not induce reporter gene activity. Therefore, RARE2 is a real RARE in the context of the aromatase promoter I.4.

The results of the mutagenesis, EMSA, and ChIP experiments clearly indicate RARE2 to be essential for the retinoid-dependent reporter gene expression and formation of RAR $\alpha$-containing DNA-protein complexes. However, reporter gene assays revealed that an additional promoter region upstream of RARE2 is necessary for retinoid-mediated induction. This $95 \mathrm{bp}$ sequence $(-256$ to -162$)$ of the 467 bp promoter fragment contains two of the putative RAREs, RARE1a and RARE1b, that are not functionally relevant. This was shown in the mutagenesis experiments, and it is corroborated by undetectable (RARE1a) or at most weak (RARE1b) complex formation in EMSAs, which is not affected by at-RA treatment (Supplementary Figure 4, see section on supplementary data given at the end of this article). Therefore, the region $(-256$ to -162$)$ seems to contain an elusive permissive element for the retinoidmediated activation of promoter I.4. At this point, we have no clues to the identity of that element.

Interestingly, the basal induction of promoter I.4-driven reporter gene activity depends only on the presence of an intact RARE2. This was shown using constructs lacking the $(-256$ to -162$)$ region. Therefore, RARE2 is necessary not only for retinoid-mediated induction, but also for basal promoter I.4 activity. This notion is corroborated by the results of band shift experiments, where a marked binding of a RAR $\alpha$-containing complex to RARE2 was detected in unstimulated cells. The formation of the RAR $\alpha /$ RARE2 complexes was clearly increased in the presence of retinoids, which is consistent with a function in a retinoid-dependent mechanism. Whether complex formation under basal conditions is also retinoid dependent cannot be unequivocally clarified at the moment, since cells may have used stored retinoids.

At the protein level, only RAR $\alpha$ expression was readily detectable in the preadipocyte-like cells used (BAFs and 3T3-L1 cells), whereas RAR $\beta$ or RAR $\gamma$ expression was sparse. This appears to be in contradiction to published work. However, previous studies on RAR expression in adipose tissue were confined to adipocytes or mRNA expression in preadipocytes (Kamei et al. 1993, Kawada et al. 2000). Thus, the retinoid-dependent induction of aromatase promoter I.4 activation in BAFs is mediated by the most abundant RAR isoform in these cells, RAR $\alpha$, as demonstrated in the ChIP experiments.

The RARE2-mediated induction of aromatase promoter I. 4 activation by retinoids can be clearly distinguished from the inhibitory effects of RXR ligands on aromatase activity induction in adipose tissue cells. At-RA and 9cis-RA are natural ligands of the RAR family of receptors responsible for the induction of promoter I.4 activation via RARE2 (this study). On the other hand, rexinoids - ligands of RXRs exert their inhibitory effects on preadipocyte aromatase activity induction either via PPAR $\gamma /$ RXR heterodimers or via competition with liver receptor homolog 1 signaling, as shown by Evan R Simpsons group previously (Rubin et al. 2002, Safi et al. 2005).

Currently, there is only one other known aromatase promoter where retinoids are involved in aromatase activity induction: promoter I.1, which is used in placenta or choriocarcinoma cells and is activated by RAR and RXR ligands (Sun et al. 1998). In addition, these ligands have been found to induce aromatase activity in the MCF-7 breast cancer cell line via promoter I.1, although a response element has not been identified (Mu et al. 2000).

Given the high specificity of retinoids for aromatase activity induction via promoter I.4 in adipose tissue cells, it is likely that this pathway is involved in the regulation of aromatase expression in normal adipose tissue with predominant promoter I.4 usage (Simpson 2004). The high variability in aromatase activities found in tissue samples obtained from different donors is not easily explained by differences in glucocorticoid concentrations alone, as these largely reflect blood concentrations. On the other hand, the availability of RA within adipose tissue largely depends on local release from stored retinyl esters brought about by hormone-sensitive lipase (Strom et al. 2009), an enzyme whose activity is regulated within wide margins.

Interestingly, increased availability of retinoids within adipose tissue could contribute to elevated aromatase activity in adipose tissue via an additional mechanism: retinoids inhibit the differentiation of preadipocytes (BAFs) into mature adipocytes (Stone \& Bernlohr 1990, Antras et al. 1991). As aromatase is expressed in the preadipocyte fraction of cells (Ackerman et al. 1981), (relative) accumulation of preadipocytes will yield higher aromatase activity in relation to tissue masses.

Published by Bioscientifica Ltd. 
A developing estrogen-dependent breast tumor will find a highly favorable environment in a region of adipose tissue rich in estrogen-synthesizing preadipocytes and in fact malignant breast tumors are preferentially found in breast quadrants with the highest aromatase expression and activities (O'Neill et al. 1988, Bulun et al. 1993). Thus, the correlation of adipose tissue retinoid contents and breast cancer risk (Zaroukian et al. 2005) may be based on the induction of aromatase activity by retinoids at least in an early phase of tumor development. Aromatase activity induction in preadipocytes/BAFs in the vicinity of established tumors largely results from tumor-derived factors, such as prostaglandin $\mathrm{E}_{2}$, that activate transcription via promoter II (Zhao et al. 1996a, Zhou et al. 2001); retinoids do not activate this promoter. But even in established tumors, retinoids, more precisely RAR $\alpha$ ligands such as at-RA and 9cis-RA, may be responsible for the albeit smaller increase in the amounts of promoter I.4-derived aromatase transcripts in tumor-surrounding adipose tissue when compared with normal adipose tissue, which has been reviewed previously (Simpson 2004).

Some of the cytokines involved in promoter I.4 activation also cause the desmoplastic reaction leading to increased BAF content in adipose tissue surrounding breast tumors (Meng etal. 2001). These cytokines, e.g. TNF $\alpha$, via the induction of insulin resistance, also stimulate lipolysis in adipocytes (Uysal et al. 1997). As local lipolysis is the most likely source of retinoids in adipose tissue (Strom et al. 2009), RAR $\alpha$-mediated aromatase activity induction in BAFs will be stimulated. Interestingly, for the myofibroblasts of breast tumor stroma, Giguere's group has shown that RAR $\beta$ promotes tumorigenesis via the induction of a chemokine/ErbB2 signaling pathway (Liu et al. 2011). This suggests that the different RAR isoforms contribute to breast cancer development in a cell type-specific manner. Herein, we provide evidence that retinoid-mediated induction of aromatase activity could be involved in the generation of a local estrogenic environment favoring breast tumor growth.

\section{Supplementary data}

This is linked to the online version of the paper at http://dx.doi.org/10.1530/ JME-12-0129.

\section{Declaration of interest}

The authors declare that there is no conflict of interest that could be perceived as prejudicing the impartiality of the research reported.

\section{Funding}

This research did not receive any specific grant from any funding agency in the public, commercial or not-for-profit sector.

\section{Author contribution statement}

$J \mathrm{~W}, \mathrm{M} \mathrm{E}$, and $\mathrm{M} S$ conceived the experiments. JW, M E, M M, G E, and M S conducted the experiments, analyzed, and discussed the data, and approved the final manuscript. J W and M S wrote the manuscript.

\section{Acknowledgements}

The authors acknowledge Simon Pankonin for provision of some reporter constructs, Daniel Kritsch for the establishment of the RAR immunofluorescence protocol, and $\mathrm{Dr}$ Otmar Huber for critical discussion of the manuscript.

\section{References}

Ackerman GE, Smith ME, Mendelson CR, MacDonald PC \& Simpson ER 1981 Aromatization of androstenedione by human adipose tissue stromal cells in monolayer culture. Journal of Clinical Endocrinology and Metabolism 53 412-417. (doi:10.1210/jcem-53-2-412)

Agarwal VR, Bulun SE, Leitch M, Rohrich R \& Simpson ER 1996 Use of alternative promoters to express the aromatase cytochrome P450 (CYP19) gene in breast adipose tissues of cancer-free and breast cancer patients. Journal of Clinical Endocrinology and Metabolism 81 3843-3849. (doi:10.1210/jc.81.11.3843)

Altschul SF, Madden TL, Schaffer AA, Zhang J, Zhang Z, Miller W \& Lipman DJ 1997 Gapped BLAST and PSI-BLAST: a new generation of protein database search programs. Nucleic Acids Research 25 3389-3402. (doi:10.1093/nar/25.17.3389)

Antras J, Lasnier F \& Pairault J 1991 Adipsin gene expression in 3T3-F442A adipocytes is posttranscriptionally down-regulated by retinoic acid. Journal of Biological Chemistry 266 1157-1161.

Bradford MM 1976 A rapid and sensitive method for the quantitation of microgram quantities of protein utilizing the principle of protein-dye binding. Analytical Biochemistry 72 248-254. (doi:10.1016/00032697(76)90527-3)

Bulun SE \& Simpson ER 1994 Regulation of aromatase expression in human tissues. Breast Cancer Research and Treatment 30 19-29. (doi:10.1007/ BF00682738)

Bulun SE, Price TM, Aitken J, Mahendroo MS \& Simpson ER 1993 A link between breast cancer and local estrogen biosynthesis suggested by quantification of breast adipose tissue aromatase cytochrome P450 transcripts using competitive polymerase chain reaction after reverse transcription. Journal of Clinical Endocrinology and Metabolism $\mathbf{7 7}$ 1622-1628. (doi:10.1210/jc.77.6.1622)

Cartharius K, Frech K, Grote K, Klocke B, Haltmeier M, Klingenhoff A, Frisch M, Bayerlein M \& Werner T 2005 MatInspector and beyond: promoter analysis based on transcription factor binding sites. Bioinformatics 21 2933-2942. (doi:10.1093/bioinformatics/bti473)

Chen D, Reierstad S, Lu M, Lin Z, Ishikawa H \& Bulun SE 2009 Regulation of breast cancer-associated aromatase promoters. Cancer Letters 273 15-27. (doi:10.1016/j.canlet.2008.05.038)

Clyne CD, Speed CJ, Zhou J \& Simpson ER 2002 Liver receptor homologue-1 (LRH-1) regulates expression of aromatase in preadipocytes. Journal of Biological Chemistry 277 20591-20597. (doi:10.1074/jbc.M201117200)

Green H \& Meuth M 1974 An established pre-adipose cell line and its differentiation in culture. Cell 3 127-133. (doi:10.1016/00928674(74)90116-0)

Kamei Y, Kawada T, Kazuki R \& Sugimoto E 1993 Retinoic acid receptor $\gamma 2$ gene expression is up-regulated by retinoic acid in 3T3-L1 preadipocytes. Biochemical Journal 293 807-812.

Kawada T, Kamei Y, Fujita A, Hida Y, Takahashi N, Sugimoto E \& Fushiki T 2000 Carotenoids and retinoids as suppressors on adipocyte differentiation via nuclear receptors. Biofactors 13 103-109. (doi:10.1002/biof.5520130117) 
Kiefer FW, Vernochet C, O'Brien P, Spoerl S, Brown JD, Nallamshetty S, Zeyda M, Stulnig TM, Cohen DE, Kahn CR et al. 2012 Retinaldehyde dehydrogenase 1 regulates a thermogenic program in white adipose tissue. Nature Medicine 18 918-925. (doi:10.1038/nm.2757)

Laemmli UK 1970 Cleavage of structural proteins during the assembly of the head of bacteriophage T4. Nature 227 680-685. (doi:10.1038/ 227680a0)

Liu X, Nugoli M, Laferriere J, Saleh SM, Rodrigue-Gervais IG, Saleh M, Park M, Hallett MT, Muller WJ \& Giguere V 2011 Stromal retinoic acid receptor $\beta$ promotes mammary gland tumorigenesis. PNAS 108 774-779. (doi:10.1073/pnas.1011845108)

Meng L, Zhou J, Sasano H, Suzuki T, Zeitoun KM \& Bulun SE 2001 Tumor necrosis factor $\alpha$ and interleukin 11 secreted by malignant breast epithelial cells inhibit adipocyte differentiation by selectively down-regulating CCAAT/enhancer binding protein $\alpha$ and peroxisome proliferator-activated receptor $\gamma$ : mechanism of desmoplastic reaction. Cancer Research $612250-2255$.

Mu YM, Yanase T, Nishi Y, Hirase N, Goto K, Takayanagi R \& Nawata H 2000 A nuclear receptor system constituted by RAR and RXR induces aromatase activity in MCF-7 human breast cancer cells. Molecular and Cellular Endocrinology 166 137-145. (doi:10.1016/S0303-7207 (00)00273-2)

O'Neill JS, Elton RA \& Miller WR 1988 Aromatase activity in adipose tissue from breast quadrants: a link with tumour site. BMJ 296 741-743. (doi:10.1136/bmj.296.6624.741)

Pfaffl MW 2001 A new mathematical model for relative quantification in real-time RT-PCR. Nucleic Acids Research 29 e45. (doi:10.1093/nar/ 29.9.e45)

Rubin GL, Zhao Y, Kalus AM \& Simpson ER 2000 Peroxisome proliferatoractivated receptor $\gamma$ ligands inhibit estrogen biosynthesis in human breast adipose tissue: possible implications for breast cancer therapy. Cancer Research 60 1604-1608

Rubin GL, Duong JH, Clyne CD, Speed CJ, Murata Y, Gong C \& Simpson ER 2002 Ligands for the peroxisomal proliferator-activated receptor $\gamma$ and the retinoid X receptor inhibit aromatase cytochrome P450 (CYP19) expression mediated by promoter II in human breast adipose. Endocrinology 143 2863-2871. (doi:10.1210/en.143.8.2863)

Safi R, Kovacic A, Gaillard S, Murata Y, Simpson ER, McDonnell DP \& Clyne CD 2005 Coactivation of liver receptor homologue-1 by peroxisome proliferator-activated receptor $\gamma$ coactivator- $1 \alpha$ on aromatase promoter $\mathrm{II}$ and its inhibition by activated retinoid $\mathrm{X}$ receptor suggest a novel target for breast-specific antiestrogen therapy. Cancer Research $\mathbf{6 5}$ 11762-11770. (doi:10.1158/0008-5472.CAN-05-2792)

Sambrook J \& Russell DW 2001 In Molecular Cloning: A Laboratory Manual, Edn3. Cold Spring Harbor, NY,USA: Cold Spring Harbor Laboratory Press.

Schmidt M \& Loffler G 1994 Induction of aromatase in stromal vascular cells from human breast adipose tissue depends on cortisol and growth factors. FEBS Letters 341 177-181. (doi:10.1016/0014-5793(94)80452-4)

Schmidt M \& Loffler G 1998 Induction of aromatase activity in human adipose tissue stromal cells by extracellular nucleotides - evidence for P2-purinoceptors in adipose tissue. European Journal of Biochemistry 252 147-154. (doi:10.1046/j.1432-1327.1998.2520147.x)

Schmidt M, Renner C \& Loffler G 1998 Progesterone inhibits glucocorticoid-dependent aromatase induction in human adipose fibroblasts. Journal of Endocrinology 158 401-407. (doi:10.1677/joe.0.1580401)

Simpson ER 2003 Sources of estrogen and their importance. Journal of Steroid Biochemistry and Molecular Biology 86 225-230. (doi:10.1016/ S0960-0760(03)00360-1)

Simpson ER 2004 Aromatase: biologic relevance of tissue-specific expression. Seminars in Reproductive Medicine 22 11-23. (doi:10.1055/ s-2004-823023)
Simpson ER, Ackerman GE, Smith ME \& Mendelson CR 1981 Estrogen formation in stromal cells of adipose tissue of women: induction by glucocorticosteroids. PNAS 78 5690-5694. (doi:10.1073/pnas.78.9.5690)

Simpson ER, Mahendroo MS, Means GD, Kilgore MW, Hinshelwood MM, Graham-Lorence S, Amarneh B, Ito Y, Fisher CR, Michael MD et al. 1994 Aromatase cytochrome P450, the enzyme responsible for estrogen biosynthesis. Endocrine Reviews 15 342-355. (doi:10.1210/edrv-15-3-342)

Stone RL \& Bernlohr DA 1990 The molecular basis for inhibition of adipose conversion of murine 3T3-L1 cells by retinoic acid. Differentiation 45 119-127. (doi:10.1111/j.1432-0436.1990.tb00465.x)

Strom K, Gundersen TE, Hansson O, Lucas S, Fernandez C, Blomhoff R \& Holm C 2009 Hormone-sensitive lipase (HSL) is also a retinyl ester hydrolase: evidence from mice lacking HSL. FASEB Journal $\mathbf{2 3}$ 2307-2316. (doi:10.1096/fj.08-120923)

Sun T, Zhao Y, Mangelsdorf DJ \& Simpson ER 1998 Characterization of a region upstream of exon I.1 of the human CYP19 (aromatase) gene that mediates regulation by retinoids in human choriocarcinoma cells. Endocrinology 139 1684-1691. (doi:10.1210/en.139.4.1684)

Taylor JD, Ackroyd AJ \& Halford SE 1994 The gel shift assay for the analysis of DNA-protein interactions. In DNA-Protein Interactions: Principles and Protocols, pp 263-279. Ed GG Kneale. Totowa, NJ: Humana Press.

Uysal KT, Wiesbrock SM, Marino MW \& Hotamisligil GS 1997 Protection from obesity-induced insulin resistance in mice lacking TNF- $\alpha$ function. Nature 389 610-614. (doi:10.1038/39335)

Weiske J \& Huber O 2006 The histidine triad protein Hint1 triggers apoptosis independent of its enzymatic activity. Journal of Biological Chemistry 281 27356-27366. (doi:10.1074/jbc.M513452200)

Zaroukian S, Pineault R, Gandini S, Lacroix A \& Ghadirian P 2005 Correlation between nutritional biomarkers and breast cancer: a casecontrol study. Breast 14 209-223. (doi:10.1016/j.breast.2005.01.001)

Zhang S, Tang G, Russell RM, Mayzel KA, Stampfer MJ, Willett WC \& Hunter DJ 1997 Measurement of retinoids and carotenoids in breast adipose tissue and a comparison of concentrations in breast cancer cases and control subjects. American Journal of Clinical Nutrition 66 626-632.

Zhao Y, Mendelson CR \& Simpson ER 1995a Characterization of the sequences of the human CYP19 (aromatase) gene that mediate regulation by glucocorticoids in adipose stromal cells and fetal hepatocytes. Molecular Endocrinology 9 340-349. (doi:10.1210/me.9.3.340)

Zhao Y, Nichols JE, Bulun SE, Mendelson CR \& Simpson ER 1995b Aromatase $\mathrm{P} 450$ gene expression in human adipose tissue. Role of a $\mathrm{Jak} / \mathrm{STAT}$ pathway in regulation of the adipose-specific promoter. Journal of Biological Chemistry 270 16449-16457. (doi:10.1074/jbc.270. 27.16449)

Zhao Y, Agarwal VR, Mendelson CR \& Simpson ER 1996a Estrogen biosynthesis proximal to a breast tumor is stimulated by PGE2 via cyclic AMP, leading to activation of promoter II of the CYP19 (aromatase) gene. Endocrinology 137 5739-5742. (doi:10.1210/en.137.12.5739)

Zhao Y, Nichols JE, Valdez R, Mendelson CR \& Simpson ER $1996 b$ Tumor necrosis factor- $\alpha$ stimulates aromatase gene expression in human adipose stromal cells through use of an activating protein-1 binding site upstream of promoter 1.4. Molecular Endocrinology 10 1350-1357. (doi:10.1210/me.10.11.1350)

Zhou J, Gurates B, Yang S, Sebastian S \& Bulun SE 2001 Malignant breast epithelial cells stimulate aromatase expression via promoter II in human adipose fibroblasts: an epithelial-stromal interaction in breast tumors mediated by CCAAT/enhancer binding protein $\beta$. Cancer Research 61 2328-2334.

Zhu ZR, Parviainen M, Mannisto S, Pietinen P, Eskelinen M, Syrjanen K \& Uusitupa M 1995 Vitamin A concentration in breast adipose tissue of breast cancer patients. Anticancer Research 15 1593-1596.

Received in final form 24 July 2013

Accepted 16 August 2013 http://jme.endocrinology-journals.org DOI: 10.1530/JME-12-0129
(C) 2013 Society for Endocrinology Printed in Great Britain 